\title{
Practical use of full-spectrum sustainability in the Bay of Fundy
}

\author{
Owen P. Jones $^{1}$ and Robert L. Stephenson ${ }^{1}$
}

\begin{abstract}
It is increasingly recognized that sustainability is composed of four key components: environmental, economic, social (including cultural), and institutional (or governance). Fisheries and coastal management systems, however, are heavily weighted toward biophysical and ecological aspects, thus leaving the "human dimension," i.e., social, economic, and institutional, relatively neglected. Full-spectrum sustainability (FSS) is an approach to resource management that aims to address this imbalance. Management plans are beginning to include elements of FSS, yet there are very few practical examples of successfully implemented FSS strategies. We examined and compared the potential application of two proposed FSS frameworks in the Bay of Fundy, one based on the Southwest New Brunswick Marine Advisory Committee Community Values Criteria, and the other on the Framework for Comprehensive Evaluation from the Canadian Fisheries Research Network. These were compared in structure and in their practical application to evaluation of plans for herring (Clupea harengus) management and the recovery of the North Atlantic right whale (Eubalena glacialis) in the Maritime region of Canada. Although the two frameworks differ in specific structure, both frameworks are useful in demonstrating the strengths and weaknesses of current management plans. This evaluation demonstrates that the management plans are strong in attention to ecological objectives but have gaps in the spectrum of considerations in current management planning, especially in relation to social, economic, and governance considerations. We propose that FSS frameworks can provide and should be used routinely as the basis for analysis of policies and management plans, engagement and discussion among stakeholders in participatory governance, comparison of alternative management scenarios, and the generation of advice. Use of FSS frameworks will allow better decisions on coastal activities within the context of "balanced" FSS.
\end{abstract}

Key Words: Bay of Fundy; Canada; coastal management; ecosystem approach; full-spectrum sustainability; integrated management

\section{INTRODUCTION}

The term "sustainability," although widely used in policy statements and as a context for coastal management planning, is often not well defined (Brown et al. 1987, Phillis and Andriantiatsaholiniaina 2001, Moldan et al. 2012). Within fisheries, the concept of sustainability has traditionally been viewed in purely ecological terms, i.e., avoiding the depletion of natural resources. Increasingly, however, fisheries researchers and managers are advocating for an approach that frames sustainability within the context of social-ecological systems (Ommer et al. 2011, 2012, Kittenger et al. 2013). This method treats sustainability as interacting modules or "pillars" that include the environment, the economy, society (including culture), and institutions (governance; Charles 1994, Rindorf et al. 2017b, Stephenson et al. 2017).

Integrating the four pillars of sustainability into fisheries governance is a major challenge (e.g., Rindorf et al. 2017b, Stephenson et al. 2017, Benson and Stephenson 2018). Current fisheries assessment and management plans focus almost exclusively on ecological performance and neglect the "human dimension" made up of social, economic, and governance aspects (Symes and Phillipson 2009, Coulthard et al. 2011, Gutiérrez et al. 2011). Although it is true that there has been increasing emphasis on linking ecological and economic sustainability, such as through the popular concept of maximum sustainable yield and variants, this falls short of the diverse considerations of ecological, social, cultural, and institutional or governance objectives required of a social-ecological systems approach (e.g., Rindorf et al. 2017a). Failure to consider the human dimension within social-ecological systems has been implicated in reduced resilience of these systems (Kooiman et al. 2005, Kittinger et al. 2013) and the failure of fisheries to obtain or maintain social license (e.g., Haward et al. 2013, Kelly et al. 2017). Increasingly, more holistic approaches to fisheries governance such as ecosystem-based management assert that the involvement of the human dimension within planning is critical to the success of a fishery, and that the needs of coastal communities must be considered to protect the adjacent coastal environment (see, e.g., Sharp and Latch 2003, Long et al. 2015, 2017). We suggest that successful management of fisheries and other coastal activities requires "full-spectrum" evaluation (see, e.g., Foley et al. 2018) and an appropriate sustainability framework that is capable of integrating objectives across the four pillars, i.e., ecological, social/ cultural, economic, and institutional, in management (see, e.g., Stephenson et al. 2018, 2019 and references therein).

We compare and evaluate two frameworks that demonstrate strong potential for full-spectrum sustainability (FSS) planning in the Bay of Fundy region of eastern Canada. Recognizing that successful implementation of FSS will require demonstration and "proof of concept," we evaluated these two frameworks for use in the same applied situations. We compared the contents of each framework and then used both frameworks to perform policy evaluations for actual and hypothetical policy scenarios in the Bay of Fundy. We hope that this exercise will demonstrate the benefits of adopting a full-spectrum approach to coastal management, as well as highlighting how the frameworks may be improved for future use.

\section{COMPARISON OF TWO POTENTIAL FRAMEWORKS}

This volume defines FSS as a perspective that accounts for the diversity of relevant considerations or objectives of socialecological systems, including ecological, economic, social/ cultural, and institutional or governance. We selected two frameworks, with the potential to become FSS frameworks, that have been proposed for use in the Bay of Fundy: the Community

${ }^{1}$ Canadian Fisheries Research Network, Fisheries and Oceans Canada and University of New Brunswick, St. Andrews Biological Station, St. Andrews, New Brunswick 
Values Criteria (CVC; Appendix 1), developed by the Southwest New Brunswick Marine Resource Planning Initiative (MRPI; MRPD Steering Committee 2009), and the Framework for Comprehensive Evaluation, developed by the Canadian Fisheries Research Network (CFRN; Appendix 2; Stephenson et al. 2019).

The Southwest New Brunswick Community Values Criteria (hereafter the SWNB CVC; Table 1) were developed by the MRPI, a citizen-led planning process that began in 2004 to address marine space conflicts in the Bay of Fundy and move toward a more integrated and collaborative approach to planning and management of marine activities. The development of the CVC framework was a grassroots initiative, derived from 1000 written responses by community members in 2006 , a year of one-on-one and group consultations in 2007, and 8 weeks of community consultations in 2008 (MRPD Steering Committee 2009). Results of the consultations demonstrated very clearly that many of the things people care about, i.e., community values, are inadequately considered in management. The CVC framework is made up of 16 elements considered by surveyed community members to be important to sustainability. The framework is composed of 4 ecological, 5 economic, 3 social, and 4 cultural objectives (from MRPD Steering Committee 2009).

Table 1. Southwest New Brunswick Marine Advisory Committee Community Values Criteria (MRPD Steering Committee 2009).

\begin{tabular}{llll}
\hline \hline Ecological & Economic & Social & Cultural \\
\hline 1. Habitat & 5. Local & 10. Equal & 13. Cumulative \\
& employment & access & impact \\
2. Species & 6. Livelihoods & $\begin{array}{l}\text { 11. Community } \\
\text { health }\end{array}$ & $\begin{array}{l}\text { 14. Heritage } \\
\text { sites }\end{array}$ \\
& & 12. Public & 15. Cultural \\
3. Chemical and & 7. Sustainability \\
biological & perception & 16. Indigenous \\
4. Physical & 8. Economic & & rights \\
& diversification & & \\
& 9. New & & \\
& investment & &
\end{tabular}

Our second framework, the Canadian Fisheries Research Network Framework for Comprehensive Evaluation (hereafter the CFRN framework) was developed by an interdisciplinary team of 50 academics, industry (fish harvesters), and Department of Fisheries and Oceans (DFO) members (Thompson et al. 2019), with the explicit aim of providing a basis for comprehensive evaluation of fisheries sustainability (Stephenson et al. 2018, 2019; Foley, Pinkerton, Wiber, et al., unpublished manuscript). The CFRN framework was the result of a review of Canadian fisheries-related policies and international agreements, as well as many meetings and considerable deliberation of the project team between 2010 and 2016 (discussed by Stephenson et al. 2019). The exercise revealed that current management has been focused on a subset of primarily ecological aspects of sustainability. The resulting framework has 13 candidate objectives spanning the 4 pillars of sustainability (Table 2; Stephenson et al. 2019), each linked with statements from Canadian policies and international agreements, and all with candidate performance indicators. The CFRN framework is composed of 3 ecological, 4 economic, 3 social/cultural, and 3 institutional objectives.

The two frameworks share several features. The most obvious is that they both employ a more comprehensive approach to the concept of sustainability; that is, they emphasize the use of social performance indicators rather than the traditional ecological or economic criteria. In addition, both frameworks were created using participatory methods from the outset. The CVC framework is based on the results of surveys conducted with SWNB constituents. The CFRN's framework was a product of stakeholder collaborations from industry, academia, and government who were all interested in improving fisheries management in Canada. Finally, in terms of application, both frameworks were proposed as tools to operationalize a more holistic view of management considerations. Both can be used to articulate the spectrum of sustainability and to judge how well "balanced" a policy proposal or management plan is across a suite of considerations. Each framework is able to demonstrate how comprehensive a particular policy or plan might be and how it is weighted, for example, toward ecological sustainability or toward economic performance.

Table 2. Canadian Fisheries Research Network framework elements of operational candidate objectives (Stephenson et al. 2019).

\begin{tabular}{|c|c|c|c|}
\hline Ecological & Economic & $\begin{array}{l}\text { Social and } \\
\text { Cultural }\end{array}$ & Institutional \\
\hline $\begin{array}{l}\text { 1. Productivity } \\
\text { and trophic } \\
\text { structure }\end{array}$ & $\begin{array}{l}\text { 4. Economic } \\
\text { viability and } \\
\text { prosperity }\end{array}$ & $\begin{array}{l}\text { 8. Sustainable } \\
\text { communities }\end{array}$ & $\begin{array}{l}\text { 11. Obligations } \\
\text { to law and } \\
\text { indigenous } \\
\text { peoples }\end{array}$ \\
\hline 2. Biodiversity & $\begin{array}{l}\text { 5. Sustainable } \\
\text { livelihoods }\end{array}$ & $\begin{array}{l}\text { 9. Health and } \\
\text { well-being }\end{array}$ & $\begin{array}{l}\text { 12. Good } \\
\text { governance } \\
\text { structure }\end{array}$ \\
\hline $\begin{array}{l}\text { 3. Habitat and } \\
\text { ecosystem } \\
\text { integrity }\end{array}$ & $\begin{array}{l}\text { 6. Distribution } \\
\text { of access and } \\
\text { benefits } \\
\text { 7. Regional } \\
\text { economic } \\
\text { benefits to } \\
\text { community }\end{array}$ & $\begin{array}{l}\text { 10. Ethical } \\
\text { fisheries }\end{array}$ & $\begin{array}{l}\text { 13. Effective } \\
\text { decision- making } \\
\text { process }\end{array}$ \\
\hline
\end{tabular}

Despite their similarities, there are differences between the two frameworks that result in significantly different outcomes when each is applied. Perhaps the most important is in how each framework defines its pillars of sustainability. The CVC framework divides its criteria into economic, ecological, social, or cultural elements, whereas the CFRN framework criteria is grouped as economic, ecological, social/cultural, or institutional/ governance. There are two important distinctions. The first is the CFRN's inclusion of an institutional/governance pillar. Effective, transparent governance from strong, stable institutions is increasingly viewed as paramount to sustainability ("strong institutions" is listed as goal 16 of the United Nations Sustainable Development Goals) and therefore should be included as a standalone pillar in any full-spectrum suite of indicators. The second important distinction is that the CVC framework separates social and cultural elements. Although there might be cases when it is important to label certain criteria as either social or cultural, the CVC framework does not seem to have a clear definition for each. For example, the "equal access" indicator is labeled as social, whereas "cumulative impacts" is listed under cultural.

Following on from this point, there is another difference between the applicability of each framework. On the one hand, each of 
Table 3. Desktop Community Values Criteria (CVC) evaluation of 2013 Herring Plan. DFO, Department of Fisheries and Oceans; NM, no mention.

\begin{tabular}{|c|c|c|c|}
\hline Category & Objective & Reference & Score \\
\hline \multirow[t]{4}{*}{ Ecological } & 1. Habitat & $\begin{array}{l}\text { "Do not cause unacceptable modification to habitat in order to safeguard both physical } \\
\text { and chemical properties of the ecosystem" (DFO 2013:8); "Manage area disturbed of } \\
\text { habitat" (DFO 2013:11); "Conservation objectives ... require consideration of the impact } \\
\text { of the fishery not only on the target species but also on non-target species and habitat } \\
\text { (DFO 2013:8)" }\end{array}$ & A \\
\hline & 2. Species & $\begin{array}{l}\text { "Conservation objectives ... require consideration of the impact of the fishery not only on } \\
\text { the target species but also on non-target species and habitat" (DFO 2013:8); "Control } \\
\text { unintended incidental mortality for spotted wolfish, Northern wolfish and white shark"; } \\
\text { "Control unintended incidental mortality for all non-retained species" (DFO 2013:11) }\end{array}$ & A \\
\hline & 3. Chemical and biological & $\begin{array}{l}\text { "Do not cause unacceptable modification to habitat in order to safeguard both physical } \\
\text { and chemical properties of the ecosystem" (DFO 2013:8) }\end{array}$ & A \\
\hline & 4. Physical & $\begin{array}{l}\text { "Do not cause unacceptable modification to habitat in order to safeguard both physical } \\
\text { and chemical properties of the ecosystem" (DFO 2013:8) }\end{array}$ & A \\
\hline \multirow[t]{5}{*}{ Economic } & 5. Local employment & "Help create the circumstances for economically prosperous fisheries" (DFO 2013:8) & B \\
\hline & 6. Livelihoods & $\begin{array}{l}\text { "Limit inflexibility in policy and licensing among individual enterprises/licence holders"; } \\
\text { "Limit inability for self-adjustment to overcapacity relative to resource availability"; } \\
\text { "Minimize instability in access to resources and allocations" (DFO 2013:12) }\end{array}$ & A \\
\hline & 7. Sustainability & $\begin{array}{l}\text { "Limit inability for self-adjustment to overcapacity relative to resource availability" (DFO } \\
\text { 2013:12) }\end{array}$ & B \\
\hline & 8. Economic diversification & $\begin{array}{l}\text { "Limit inflexibility in policy and licensing among individual enterprises/licence holders" } \\
\text { (DFO 2013:12) }\end{array}$ & B \\
\hline & 9. New investment & $\mathrm{NM}$ & $\mathrm{C}$ \\
\hline \multirow[t]{3}{*}{ Social } & 10. Equal access & "Minimize instability in access to resources and allocations" (DFO 2013:12) & B \\
\hline & 11. Community health & NM & $\mathrm{C}$ \\
\hline & 12. Public perception & NM & $\mathrm{C}$ \\
\hline \multirow[t]{4}{*}{ Cultural } & 13. Cumulative impact & NM & $\mathrm{C}$ \\
\hline & 14. Heritage sites & NM & $\mathrm{C}$ \\
\hline & 15. Cultural heritage & NM & $\mathrm{C}$ \\
\hline & 16. Indigenous rights & $\begin{array}{l}\text { "Minimize instability in access to resources and allocations" (DFO 2013:12); "The social, } \\
\text { cultural and economic objectives reflect the aboriginal right to fish for food, social and } \\
\text { ceremonial purpose" (DFO 2013:8); "Provide access for food, social and ceremonial } \\
\text { purposes" (DFO 2013:11); "Issue food, social and ceremonial licences as required"; "... } \\
\text { respect aboriginal and treaty rights to fish" (DFO 2013:8) }\end{array}$ & A \\
\hline
\end{tabular}

the CFRN's performance indicators was a product of extensive background research, input from experts and academics, and vetting during an extensive series of case studies involving researchers from across Canada. This has resulted in a wellorganized framework with clear criteria and instructions for using each performance indicator. On the other hand, the CVC framework, despite sourcing its content from an extensive polling campaign, does not demonstrate the same level of real-world applicability. The CVC framework has multiple performance criteria that seem to overlap in terms of scope, for example, the use of "heritage sites" and "cultural heritage" within the cultural pillar or "local employment" and "livelihoods" within the economic pillar. Further, despite being more than a decade old, the CVC framework has yet to be used in any policy appraisal and is therefore as yet untested.

\section{USE OF THE FRAMEWORKS TO EVALUATE TWO MANAGEMENT PLANS}

We used the CVC and CFRN frameworks to evaluate two management plans: the 2013 Herring Plan (DFO 2013) and the 2016 Action Plan for the North Atlantic Right Whale (DFO 2016). Both management plans are in use in the Maritime region of Canada, affect stakeholders in coastal communities, and were produced by DFO. In the Bay of Fundy, the government of
Canada has jurisdiction over fisheries and oceans management, including herring (Clupea harengus) and right whales (Eubalena glacialis). The 2013 Herring Plan is an integrated fisheries management plan used by DFO to guide the conservation and sustainable use of marine resources. Herring is a traditionally important commercial species in the Maritimes; however, population abundance of the four southwest Nova Scotia herring stocks (4VWX zones) has declined since 2001, despite reduced catch levels in recent years (DFO 2013). Through our evaluations, we wanted to investigate the level to which the 2013 Herring Plan addressed not only ecological and economic issues, but also societal and institutional aspects. We matched references within the management plan to both the CVC and CFRN objectives (Tables 1 and 2) and gave each objective a simple color score: detailed mention indicated by A or green; scarce mention, by B or yellow; and no mention, by $\mathrm{C}$ or orange. The results are presented in Tables 3 and 4 .

We repeated this exercise with the 2016 Action Plan for the North Atlantic Right Whale. The North Atlantic right whale is an endangered migratory whale whose population is estimated to be about 500 individuals. The action plan is meant to contribute to the recovery goal of the right whale, as set out in the strategy: "To achieve an increasing trend in population abundance over three 
Table 4. Desktop Canadian Fisheries Research Network evaluation of the 2013 Herring Plan (Department of Fisheries and Oceans [DFO] 2013). NM, no mention.

\begin{tabular}{|c|c|c|c|}
\hline Category & Objectives & Reference in Text & Score \\
\hline \multirow[t]{3}{*}{ Ecological } & 1. Productivity and trophic structure & $\begin{array}{l}\text { "Control unintended incidental mortality for spotted wolfish, Northern wolfish } \\
\text { and white shark" (DFO 2013:11); "Control unintended incidental mortality for } \\
\text { all non-retained species" (DFO 2013:11) }\end{array}$ & A \\
\hline & 2. Biodiversity & $\begin{array}{l}\text { "The Limit Reference Point ... [has] the objective of avoiding negative impacts } \\
\text { to the ecosystem and long-term loss of fishing opportunities" (DFO 2013:4) }\end{array}$ & $\mathrm{B}$ \\
\hline & 3. Habitat and ecosystem integrity & $\begin{array}{l}\text { "Do not cause unacceptable modification to habitat in order to safeguard both } \\
\text { physical and chemical properties of the ecosystem" (DFO 2013:8); "Manage } \\
\text { area disturbed of habitat" (DFO 2013:11); "Conservation objectives ... require } \\
\text { consideration of the impact of the fishery not only on the target species but also } \\
\text { on non-target species and habitat" (DFO 2013:8) }\end{array}$ & A \\
\hline \multirow[t]{4}{*}{ Economic } & 4. Economic viability and prosperity & $\begin{array}{l}\text { "Help create the circumstances for economically prosperous fisheries" (DFO } \\
\text { 2013:8) }\end{array}$ & $\mathrm{B}$ \\
\hline & 5. Sustainable livelihoods & NM & $\mathrm{C}$ \\
\hline & $\begin{array}{l}\text { 6. Distribution of access and } \\
\text { benefits }\end{array}$ & "Minimize instability in access to resources and allocations" (DFO 2013:8) & $\mathrm{B}$ \\
\hline & $\begin{array}{l}\text { 7. Regional economic benefits to } \\
\text { community }\end{array}$ & NM & $\mathrm{C}$ \\
\hline \multirow[t]{3}{*}{ Social } & 8. Health and well-being & NM & $\mathrm{C}$ \\
\hline & 9. Sustainable communities & NM & $\mathrm{C}$ \\
\hline & 10. Ethical fisheries & "Support certification for sustainability" (DFO 2013:12) & B \\
\hline \multirow[t]{3}{*}{ Institutional } & $\begin{array}{l}\text { 11. Legal obligations, including to } \\
\text { indigenous people }\end{array}$ & $\begin{array}{l}\text { "... respect aboriginal and treaty rights to fish"; "The social, cultural and } \\
\text { economic objectives reflect the aboriginal right to fish for food, social and } \\
\text { ceremonial purpose"; "Provide access for food, social and ceremonial purposes"; } \\
\text { "Issue food, social and ceremonial licences as required"; “... respect aboriginal } \\
\text { and treaty rights to fish"; "Minimize instability in access to resources and } \\
\text { allocations" (DFO 2013:8) }\end{array}$ & A \\
\hline & 12. Good governance structure & $\begin{array}{l}\text { "Limit inflexibility in policy and licensing among individual enterprises/licence } \\
\text { holders"; "Limit inability for self-adjustment to overcapacity relative to resource } \\
\text { availability" (DFO 2013:12) }\end{array}$ & A \\
\hline & $\begin{array}{l}\text { 13. Effective decision-making } \\
\text { process }\end{array}$ & NM & $\mathrm{C}$ \\
\hline
\end{tabular}

generations" (DFO 2016:iii). Through an FSS desktop evaluation, using the CVC and the CFRN frameworks, we investigated the extent to which this action plan was balanced over each pillar of sustainability. We matched references within both the management plans to the CFRN and CVC objectives and gave each objective a simple color score: detailed mention indicated by A or green; scarce mention, by B or yellow; and no mention (NM), by $\mathrm{C}$ or orange. The results are presented in Tables 5 and 6.

\section{PERFORMANCE OF THE COMMUNITY VALUES CRITERIA AND CANADIAN FISHERIES RESEARCH NETWORK FRAMEWORKS}

We compared how each framework evaluated both management plans, first plotting the results of the CVC evaluations (Fig. 1). The CVC framework indicates that both the 2013 Herring Plan and the 2016 Action Plan for the North Atlantic Right Whale perform strongly on ecological issues. This is understandable, given the conservation-focused nature of both management plans, i.e., one is set out to rebuild the herring stock, and the other to provide outright protection for right whales and other marine mammals. The CVC rates both management plans as performing poorly on societal issues (2/3 orange scores for the 2013 Herring Plan and 3/3 orange for the 2016 Action Plan for the North Atlantic Right Whale). This is probably because of the nature of the CVC societal objectives, which were not present in either
Fig. 1. Comparison of two management plans evaluated with the Community Values Criteria framework: (a) 2013 Herring Plan and (b) 2016 Action Plan for the North Atlantic Right Whale. Green scores indicate detailed mentions within the management plan, yellow scores indicate scant mention, and orange scores indicate no mention. Words within slices refer to objective category (Cult, cultural; Ecol, ecological; Econ, economic; Soc, Social), and numbers correspond to list of objectives (right).

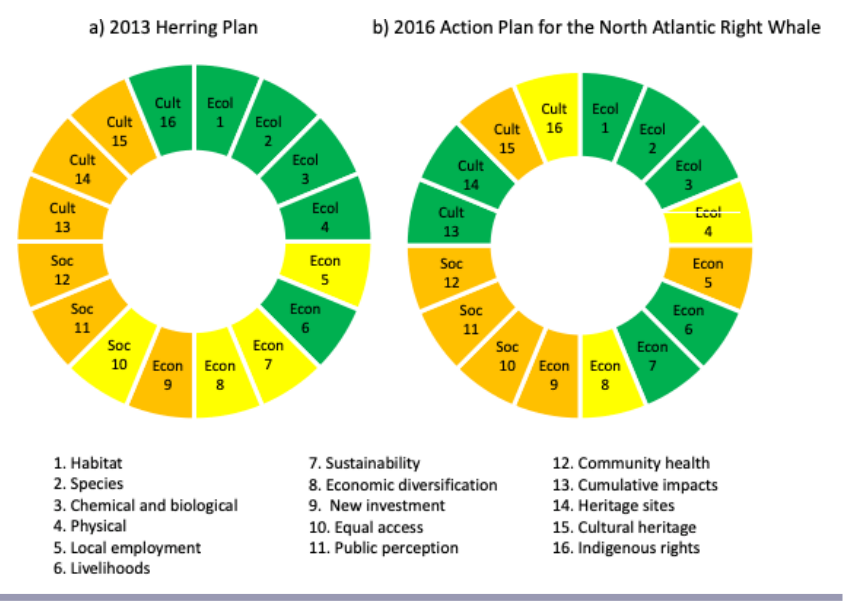


Table 5; Desktop Community Values Criteria evaluation of the 2016 Action Plan for the North Atlantic Right Whale (Department of Fisheries and Oceans [DFO] 2016). NM, no mention; SARA, Species at Risk Act.

\begin{tabular}{|c|c|c|c|}
\hline Category & Objective & Reference & Score \\
\hline \multirow[t]{4}{*}{ Ecological } & 1. Habitat & $\begin{array}{l}\text { "The plan outlines what needs to be done to achieve the population and distribution objectives } \\
\text { identified in the recovery strategy, including the measures to be taken to address the threats and } \\
\text { monitor the recovery of the species, as well as the measures to protect critical habitat. The critical } \\
\text { habitat identified in Grand Manan Basin and Roseway Basin is anticipated to be protected via a } \\
\text { SARA section 58(4) Critical Habitat Order which engages the SARA section 58(1) prohibition } \\
\text { against the destruction of critical habitat of listed endangered or threatened species in these areas." } \\
\text { "Objective 3: Reduce injury and disturbance as a result of vessel presence or exposure to } \\
\text { contaminants and other forms of habitat degradation." (DFO 2016:i) "Objective 5: Increase } \\
\text { understanding of life history characteristics, low reproductive rate, habitat and threats to recovery } \\
\text { through research." (DFO 2016:1) "DFO is leading a process to develop a network of Marine } \\
\text { Protected Areas (MPAs). While Right Whale habitat is not currently proposed as the basis of future } \\
\text { MPAs, the species' high-use habitat areas will be included as one of many layers of information } \\
\text { within a region-wide biodiversity conservation analysis currently underway. These analyses should } \\
\text { take into account Right Whale aggregations, known risk of fishery interactions, and the potential } \\
\text { management processes in place to protect species at risk." (DFO 2016:7) "Objective } 12 . \text { Monitor } \\
\text { Right Whale presence in areas outside critical habitat." "Work is needed to determine the distribution } \\
\text { of Right Whales in areas and at times of year beyond the traditional summer surveys in Canadian } \\
\text { critical habitat areas." (DFO 2016:10) }\end{array}$ & A \\
\hline & 2. Species & Protection of right whales and other marine mammals & A \\
\hline & 3. Chemical and biological & $\begin{array}{l}\text { "Objective 15. Investigate the role of 'ghost gear."' "In addition to understanding the role of actively } \\
\text { fished gear, some partners are beginning to explore the potential role of 'ghost gear' (gear that has } \\
\text { been abandoned or lost) in Right Whale entanglements. The quantities of such gear and the extent of } \\
\text { the problem it presents are poorly understood, and potential impacts of ghost gear need to be } \\
\text { investigated. In New Brunswick, the Fundy North Fishermen's Association is conducting a project to } \\
\text { investigate and remove ghost gear in the Bay of Fundy; results of this project may provide guidance } \\
\text { for additional investigations in other areas." (DFO 2016:12) }\end{array}$ & A \\
\hline & 4. Physical & Reduced noise, vessel strikes & $\mathrm{B}$ \\
\hline \multirow[t]{5}{*}{ Economic } & $\begin{array}{l}\text { 5. Economic viability and } \\
\text { prosperity }\end{array}$ & 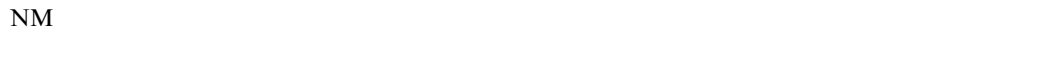 & $\mathrm{C}$ \\
\hline & 6. Support for local employment & $\begin{array}{l}\text { "Possible mitigation measures that could prevent Right Whale entanglement include temporal and/or } \\
\text { spatial closures for fisheries, changes in gear configurations, reducing the amount of gear or line in } \\
\text { the water, and others." "The Government of Canada will allow ships to travel at usual speeds in parts } \\
\text { of two shipping lanes north and south of Anticosti Island when no whales are in the area. A 15-day } \\
\text { mandatory slowdown to } 10 \text { knots will be activated within a section of the shipping lanes when a } \\
\text { North Atlantic right whale is spotted and may be extended as needed." (DFO 2016:4) }\end{array}$ & A \\
\hline & 7. Impacts to existing livelihoods & $\begin{array}{l}\text { "Possible mitigation measures that could prevent Right Whale entanglement include temporal and/or } \\
\text { spatial closures for fisheries, changes in gear configurations, reducing the amount of gear or line in } \\
\text { the water, and others." (DFO 2016:4) }\end{array}$ & A \\
\hline & 8. Financial self-sustainability & Supporting marine mammal response groups & $\mathrm{B}$ \\
\hline & $\begin{array}{l}\text { 9. Support for new local economic } \\
\text { diversification }\end{array}$ & $\mathrm{NM}$ & $\mathrm{C}$ \\
\hline \multirow[t]{3}{*}{ Social } & $\begin{array}{l}\text { 10. New investment/local economic } \\
\text { spin-offs }\end{array}$ & NM & $\mathrm{C}$ \\
\hline & 11. Marine heritage & NM & $\mathrm{C}$ \\
\hline & 12. Natural and cultural heritage & NM & $\mathrm{C}$ \\
\hline \multirow[t]{4}{*}{ Cultural } & 13. Indigenous traditions & $\begin{array}{l}\text { "Aboriginal traditional knowledge, or ATK - also referred to as Indigenous knowledge by some } \\
\text { recovery partners - is a potential source of information about historic and current distribution of } \\
\text { Right Whales that is poorly understood in the context of species recovery. Exploration of this avenue, } \\
\text { through Traditional Knowledge and current information from communal commercial Aboriginal } \\
\text { fisheries, may contribute." "Objective } 6 \text { : Support and promote collaboration for recovery between } \\
\text { government agencies, academia, environmental non-government groups, Aboriginal people, coastal } \\
\text { communities and international agencies and bodies." (DFO 2016:12) "Stewardship activities related to } \\
\text { reducing entanglement risk require ongoing funding support. DFO supports and participates in the } \\
\text { Habitat Stewardship Program (HSP) and the Aboriginal Fund for Species at Risk." "[Objective } 6 \\
\text { indicator] Are all relevant groups represented adequately, including Aboriginal partners?" (DFO } \\
\text { 2016:13) }\end{array}$ & A \\
\hline & 14. Equal access & $\begin{array}{l}\text { "Possible mitigation measures that could prevent Right Whale entanglement include temporal and/or } \\
\text { spatial closures for fisheries, changes in gear configurations, reducing the amount of gear or line in } \\
\text { the water, and others." "The Government of Canada will allow ships to travel at usual speeds in parts } \\
\text { of two shipping lanes north and south of Anticosti Island when no whales are in the area. A 15-day } \\
\text { mandatory slowdown to } 10 \text { knots will be activated within a section of the shipping lanes when a } \\
\text { North Atlantic right whale is spotted and may be extended as needed." (DFO 2016:4) }\end{array}$ & A \\
\hline & $\begin{array}{l}\text { 15. Community health and human } \\
\text { growth }\end{array}$ & NM & $\mathrm{B}$ \\
\hline & 16. Public perception & Lots of updates from DFO including Twitter updates and press releases each time there is a closure & $\mathrm{C}$ \\
\hline
\end{tabular}


Table 6. Desktop Canadian Fisheries Research Network evaluation of the 2016 Action Plan for the North Atlantic Right Whale (Department of Fisheries and Oceans [DFO] 2016). NM, no mention; SARA, Species at Risk Act.

\begin{tabular}{lll}
\hline \hline Category & Objective & Reference \\
\hline Ecological & 1. Productivity and trophic structure & NM \\
& 2. Biodiversity & "DFO is leading a process to develop a network of Marine Protected Areas
\end{tabular}

3. Habitat and ecosystem integrity

(MPAs). While Right Whale habitat is not currently proposed as the basis of

future MPAs, the species' high-use habitat areas will be included as one of many layers of information within a region-wide biodiversity conservation analysis currently underway." (DFO 2016:7)

"The plan outlines what needs to be done to achieve the population and distribution objectives identified in the recovery strategy, including the measures to be taken to address the threats and monitor the recovery of the species, as well as the measures to protect critical habitat. The critical habitat identified in Grand Manan Basin and Roseway Basin is anticipated to be protected via a SARA section 58(4) Critical Habitat Order which engages the SARA section 58(1) prohibition against the destruction of critical habitat of listed endangered or threatened species in these areas." (DFO 2016:i) "Objective 3: Reduce injury and disturbance as a result of vessel presence or exposure to contaminants and other forms of habitat degradation." (DFO 2016:1) "Objective 5: Increase understanding of life history characteristics, low reproductive rate, habitat and threats to recovery through research." (DFO 2016:1) "DFO is leading a process to develop a network of Marine Protected Areas (MPAs). While Right Whale habitat is not currently proposed as the basis of future MPAs, the species' high-use habitat areas will be included as one of many layers of information within a region-wide biodiversity conservation analysis currently underway. These analyses should take into account Right Whale aggregations, known risk of fishery interactions, and the potential management processes in place to protect species at risk." (DFO 2016:i)

"Objective 12. Monitor Right Whale presence in areas outside critical habitat." "Work is needed to determine the distribution of Right Whales in areas and at times of year beyond the traditional summer surveys in Canadian critical habitat areas." (DFO 2016:10)

Economic 4. Economic viability and prosperity 5. Sustainable livelihoods

6. Distribution of access and benefits

NM

NM

"Possible mitigation measures that could prevent Right Whale entanglement include temporal and/or spatial closures for fisheries, changes in gear configurations, reducing the amount of gear or line in the water, and others." "The Government of Canada will allow ships to travel at usual speeds in parts of two shipping lanes north and south of Anticosti Island when no whales are in the area. A 15-day mandatory slowdown to 10 knots will be activated within a section of the shipping lanes when a North Atlantic right whale is spotted and may be extended as needed." (DFO 2016:4)

7. Regional economic benefits to community "Possible mitigation measures that could prevent Right Whale entanglement include temporal and/or spatial closures for fisheries, changes in gear configurations, reducing the amount of gear or line in the water, and others." (DFO 2016:4) Temporary closures and fines for fishing and shipping violations. NM NM NM 8. Health and well-being
9. Sustainable communities 10. Ethical fisheries

$\begin{array}{ll}\text { Social } & \text { 8. Health and well-being } \\ & \begin{array}{l}\text { 9. Sustainable communities } \\ \text { 10. Ethical fisheries }\end{array} \\ \text { Institutional } & \begin{array}{l}\text { 11. Legal obligations, including to indigenous } \\ \text { peoples }\end{array}\end{array}$

"Aboriginal traditional knowledge, or ATK - also referred to as Indigenous knowledge by some recovery partners - is a potential source of information about historic and current distribution of Right Whales that is poorly understood in the context of species recovery. Exploration of this avenue, through Traditional Knowledge and current information from communal commercial Aboriginal fisheries, may contribute." (DFO 2016:12) "Objective 6: Support and promote collaboration for recovery between government agencies, academia, environmental non-government groups, Aboriginal people, coastal communities and international agencies and bodies." (DFO 2016:12) "Stewardship activities related to reducing entanglement risk require ongoing funding support. DFO supports and participates in the Habitat Stewardship Program (HSP) and the Aboriginal Fund for Species at Risk." "[Objective 6 indicator] Are all relevant groups represented adequately, including Aboriginal partners?" (DFO 2016:12)

12. Good governance structure Some protest from fishing groups Documentation from DFO website Regular updates

$\longrightarrow$

management plan. There was little mention in either plan of issues concerning equal access, public perception, or community health. The CVC gave both plans a mixed score on economic performance
(1/5 and 2/5 green scores for the 2013 Herring Plan and 2016 Action Plan for the North Atlantic Right Whale, respectively), despite both plans appearing to present abundant mitigations 
against negative economic impacts to stakeholders. This again might be because of the phrasing of the framework objectives, which might be unaligned with the wording of the management plans, i.e., neither plan made explicit mention of objective 5, "local employment," but that does not mean that either plan attempts to damage local employment. Similarly, results were mixed for cultural issues, which could again be because of the rather abstract nature of some objectives; that is, "cumulative impacts," objective 13 , is listed as a cultural objective, and there is considerable overlap between "heritage sites," objective 14, and "cultural heritage," objective 15 .

The CFRN (Fig. 2) grades both management plans less strongly on ecological issues than the CVC (2/3 green for the 2013 Herring Plan and 1/3 green for the 2016 Action Plan for the North Atlantic Right Whale). This is considered to be related to the fact that neither plan is aimed at ecosystem-level conservation but rather is focused on a single species (herring and the North Atlantic right whale). The CFRN framework scores the 2016 Action Plan for the North Atlantic Right Whale as performing marginally better than the 2013 Herring Plan on economic issues, perhaps because of its strong focus on mitigating any economic loss to fishers after whale sightings. Similar to the CVC evaluations, neither plan performs particularly well on societal/cultural issues; however, this is understandable given that neither plan was written to address issues of community well-being. Finally, the CFRN framework suggests that the 2013 Herring Plan performs marginally better than the 2016 Action Plan for the North Atlantic Right Whale on institutional elements, perhaps because of a strong commitment from the herring plan to increase the flexibility of licensing.

\section{DISCUSSION AND CONCLUSION}

Although it is increasingly recognized that management requires consideration of ecological, social (including cultural), economic, and institutional (or governance) objectives, current fisheries and coastal management systems are heavily weighted toward biophysical and ecological aspects, thus leaving the human dimension (i.e., social, economic, and institutional) relatively neglected. Neglect of the human dimension has resulted in unintended or untracked consequences, especially in social aspects such as distribution of benefits of marine activities to coastal communities, all of which has eroded confidence in management. FSS explicitly specifies consideration of all four pillars of sustainability and that diverse objectives are met. Articulation of specific objectives in management planning is a major step in having aspects discussed and monitored. Any FSS framework should improve the breadth of management considerations and therefore improve the probability of diverse objectives being met.

We have presented two frameworks, CVC and CFRN, each with the potential to be used for FSS analysis, and evaluated their performance when applied to two real-world resource management policies in the Bay of Fundy. Although both frameworks seem fairly similar at first glance, they differ in the structure of their sustainability pillars and their performance when being applied to the evaluation of real-world management plans/policies.
Fig. 2. Comparison of the two management plans evaluated with the Canadian Fisheries Research Network framework: (a) 2013 Herring Plan and (b) 2016 Action Plan for the North Atlantic Right Whale. Green scores indicate detailed mentions within the management plan, yellow scores indicate scant mention, and orange scores indicate no mention. Words within slices refer to objective category (Ecol, ecological; Econ, economic; Instit, institutional; Soc, social), and numbers correspond to list of objectives (right).

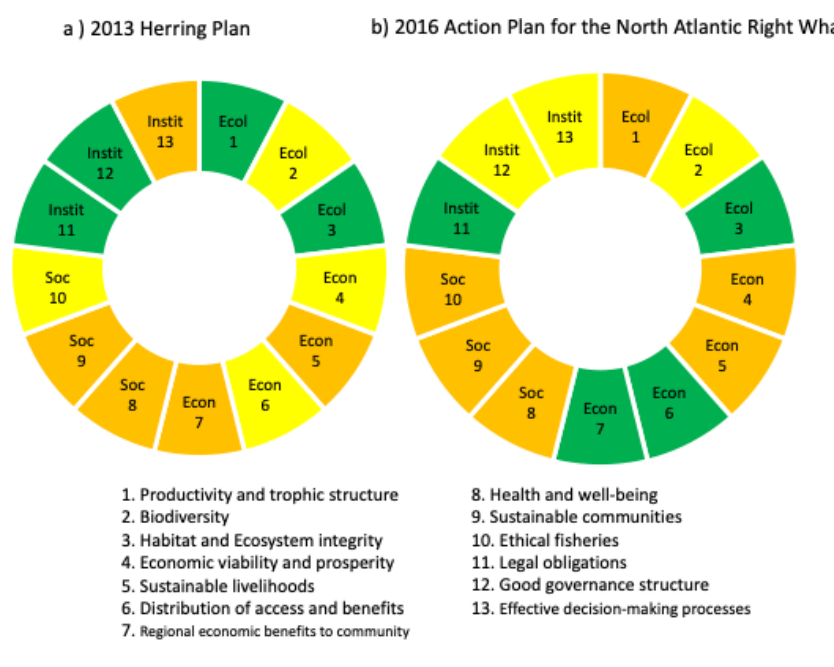

The two frameworks produced markedly different results when evaluating both the 2013 Herring Plan and 2016 Action Plan for the North Atlantic Right Whale. Part of this was because of differences in the structure of the frameworks, but part was because of differences in the articulation of objectives. The frameworks are described in generic terms, i.e., general "community values" in the case of the CVC and candidate objectives in the case of the CFRN, which were not matched exactly in the management planning. Further, there are aspects of the frameworks (e.g., local employment) that may be implicit but are not stated specifically in management planning. This points to the need for greater attention to explicit articulation of the full range of objectives of management plans. We suggest that consideration of an FSS framework would result in better articulation of such objectives in future management plan development.

The CFRN framework, because it includes an institutional pillar, is more full spectrum than the $\mathrm{CVC}$, according to the definition being used in this volume. Furthermore, we found a considerable difference in the "robustness" of each framework. After review, we concluded that the CFRN framework is a more robust framework, in particular regarding its foundation, i.e., indicators based on widespread research and real-world policies; scope, the inclusion of institutional/governance indicators; and applicability, each indicator contained clear, independent, and suitable criteria. Although the CVC framework is an interesting example of a "crowd-sourced" FSS framework, with significant potential to capture "hyperlocal" values, the framework itself needs more work before being applied as a practical evaluative tool. 
FSS frameworks have several potential applications. Their primary function is projected to be in guiding and evaluating the scope of policy or plan development. In this function, an FSS framework could provide the basis for a structured approach to policy/plan development. Use of an FSS framework would help define comprehensive scope in policy development and would assist resource managers and the general public in understanding how comprehensive and well balanced a policy is in relation to the four pillars of sustainability. This, in turn, will force policy authors to broaden the scope of their management plans and demonstrate that they have considered not just the traditional elements of sustainability (economic and environmental), but also the more holistic aspects as well (social and institutional).

FSS frameworks are also expected to be useful in comparison of alternate management scenarios, i.e., decision support, where they will allow more rigorous evaluation of how alternate scenarios meet the diverse multiple aspects of sustainability. Although there are several decision-support tools currently available to managers, e.g., cost-benefit analysis (CBA) and SWOT (strengths, weaknesses, opportunities, and threats) analysis, those tools often portray issues in black-and-white terms, i.e., good or bad. Furthermore, they demand speculation from the author as to what constitutes a cost or a benefit. For example, performing a CBA, using the CVC objectives as criteria, would involve producing a binary response to some significantly nuanced objectives, i.e., regional economic benefits to community. What distinguishes an FSS framework from other decision-making tools is an ability to avoid predictions and instead focus on the content of the management plan itself. Management plans that explicitly make mention of the four pillars of sustainability, as well as how they will mitigate negative consequences to those pillars, will perform well in an FSS evaluation.

Further, Stephenson et al. (2018) propose the use of FSS in a comparison of alternate management scenarios such that the relative pros and cons of various scenarios can be compared across a range of objectives. We believe that FSS frameworks can, and should, be used by resource managers and stakeholders to focus discussion on objectives and management scenarios and to consider alternatives in decision making. FSS frameworks are ideally suited to participatory structures in which there are diverse interests and potentially differing priorities in relation to ecological, social/cultural, economic, and governance objectives. Finally, an FSS framework would provide an obvious basis for evaluation and reporting on how well a plan or policy is performing in relation to the explicit objectives.

Explicit consideration of the full spectrum of sustainability in management planning will lead to increased monitoring of the consequences of some aspects of management decisions that are not now being tracked and should reduce unintended consequences. Further, an FSS framework provides a structure for improved management planning, structured discussion among participants in management planning regarding trade-offs and how well objectives are being met, scenario comparison, and more rigor in reporting. These considerations would improve decisions in management of coastal activities and should improve the legitimacy of management (social license). We propose that FSS frameworks can provide and should be used routinely as the basis for analysis of policies and management plans, engagement and discussion among stakeholders in participatory governance, comparison of alternative management scenarios, and the generation of advice. Use of FSS frameworks will allow better decisions on coastal activities within the context of balanced FSS.

Responses to this article can be read online at: http://www.ecologyandsociety.org/issues/responses. php/11010

\section{Acknowledgments:}

The authors would like to thank Melanie Wiber, Catriona RegnierMckellar, and Allan Debertin for their time and input in editing this paper.

\section{LITERATURE CITED}

Benson, A. J., and R. L. Stephenson. 2018. Options for integrating ecological, economic and social objectives in evaluation and management of fisheries. Fish and Fisheries 19:40-56. https://doi. org/10.1111/faf.12235

Brown, B. J., M. E. Hanson, D. M. Liverman, and R. W. Merideth, Jr. 1987. Global sustainability: toward definition. Environmental Management 11:713-719. https://doi.org/10.1007/BF01867238

Charles, A. T. 1994. Towards sustainability: the fishery experience. Ecological Economics 11:201-211. https://doi.org/10.1016/0921-8009 (94)90201-1

Coulthard S., D. Johnson, and J. A. McGregor. 2011. Poverty, sustainability and human wellbeing: a social wellbeing approach to the global fisheries crisis. Global Environmental Change 21:453-463. https://doi.org/10.1016/j.gloenvcha.2011.01.003

Department of Fisheries and Oceans (DFO). 2013. Canadian Atlantic herring (Clupea harengus) - SWNS rebuilding plan Atlantic Canada - 2013. DFO, Ottawa, Ontario, Canada. [online] URL: http://dfo-mpo.gc.ca/fm-gp/peches-fisheries/ifmp-gmp/herringhareng/herring-hareng-2013-eng.htm

Department of Fisheries and Oceans (DFO). 2016. Action plan for the North Atlantic right whale (Eubalena glacialis) in Canada: fishery interactons [proposed]. Species at Risk Act Action Plan Series. DFO, Ottawa, Ontario, Canada.

Foley, P., D. A. Okyere, and C. Mather. 2018. Alternative environmentalities: recasting the assessment of Canada's first Marine Stewardship Council-certified fishery in social terms. Ecology and Society 23(3):37. https://doi.org/10.5751/ES-10382-230337

Gutiérrez, N. L., R. Hilborn, and O. Defeo. 2011. Leadership, social capital and incentives promote successful fisheries. Nature 470:386-389. https://doi.org/10.1038/nature09689

Haward, M., J. Jabour, and J. McDonald. 2013. Small fish in a big pond: lessons from the Abel Tasman controversy. Australian Journal of Maritime and Ocean Affairs 5:22-27. https://doi. org/10.1080/18366503.2013.10815727

Kelly, R., G. T. Pecl, and A. Fleming. 2017. Social licence in the marine sector: a review of understanding and application. Marine Policy 81:21-28. https://doi.org/10.1016/j.marpol.2017.03.005 
Kittinger, J. N., E. M. Finkbeiner, N. C. Ban, K. Broad, M. H. Carr, J. E. Cinner, S. Gelcich, M. L. Cornwell, J. Z. Koehn, X. Basurto, R. Fujita, M. R. Caldwell, and L. B.Crowder. 2013. Emerging frontiers in social-ecological systems research for sustainability of small-scale fisheries. Current Opinion in Environmental Sustainability 5:352-357. https://doi.org/10.1016/ j.cosust.2013.06.008

Kooiman, J., M. Bavink, S. Jentoft, and R. Pullin. 2005. Fish for life: interactive governance for fisheries. Amsterdam University Press, Amsterdam, The Netherlands. https://doi. org/10.5117/9789053566862

Long, R. D., A. Charles, and R. L. Stephenson. 2015. Key principles of marine ecosystem-based management. Marine Policy 57:53-60. https://doi.org/10.1016/j.marpol.2015.01.013

Long, R. D., A. Charles, and R. L. Stephenson. 2017. Key principles of ecosystem-based management: the fishermen's perspective. Fish and Fisheries 18:244-253. https://doi. org/10.1111/faf.12175

Marine Resource Plan Development Steering Committee (MRPD Steering Committee). 2009. "The preferred future of the bay": recommendations towards a community based plan for the management of marine activities and space in Southwest New Brunswick Bay of Fundy. The Bay of Fundy Marine Resource Centre, Cornwallis Park, Nova Scotia, Canada.

Moldan, B., S. Janoušková, and T. Hák. 2012. How to understand and measure environmental sustainability: indicators and targets. Ecological Indicators 17:4-13. https://doi.org/10.1016/j. ecolind.2011.04.033

Ommer, R. E., R. I. Perry, K. Cochrane, and P. Cury, editors. 2011. World fisheries: a social-ecological analysis. Fish and Aquatic Resources Series 14. Wiley-Blackwell, Chichester, West Sussex, UK. https://doi.org/10.1002/9781444392241

Ommer, R. E., R. I. Perry, G. Murray, and B. Neis. 2012. Socialecological dynamism, knowledge, and sustainable coastal marine fisheries. Current Opinion in Environmental Sustainability 4:316-322. https://doi.org/10.1016/j.cosust.2012.05.010

Phillis, Y. A., and L. A. Andriantiatsaholiniaina. 2001. Sustainability: an ill-defined concept and its assessment using fuzzy logic. Ecological Economics 37(3):435-456. https://doi. org/10.1016/S0921-8009(00)00290-1

Rindorf, A., C. M. Dichmont, P. S. Levin, P. Mace, S. Pascoe, R. Prellezo, A. E. Punt, D. G. Reid, R. Stephenson, C. Ulrich, M. Vinther, and L. W. Clausen. 2017a. Food for thought: pretty good multispecies yield. ICES Journal of Marine Science 74:475-486. https://doi.org/10.1093/icesjms/fsw071

Rindorf, A., C. M. Dichmont, J. Thorson, A. Charles, L. W. Clausen, P. Degnbol, D. Garcia, N. T. Hintzen, A. Kempf, P. Levin, P. Mace, C. Maravelias, C. Minto, J. Mumford, S. Pascoe, R. Prellezo, A. E. Punt, D. G. Reid, C. Röckmann, R. L. Stephenson, O. Thebaud, G. Tserpes, and R. Voss. $2017 b$. Inclusion of ecological, economic, social, and institutional considerations when setting targets and limits for multispecies fisheries. ICES Journal of Marine Science 74:453-463. https://doi. org/10.1093/icesjms/fsw226
Sharp, S. B., and D. Lach. 2003. Integrating social values into fisheries management: a Pacific Northwest study. Fisheries 28 (4):10-15. https://doi.org/10.1577/1548-8446(2003)28[10:ISVIFM] 2.0. $\mathrm{CO} ; 2$

Stephenson, R. L., A. J. Benson, K. Brooks, A. Charles, P. Degnbol, C. M. Dichmont, M. Kraan, S. Pascoe, S. D. Paul, A. Rindorf, and M. Wiber. 2017. Practical steps toward integrating economic, social and institutional elements in fisheries policy and management. ICES Journal of Marine Science 74:1981-1989. https://doi.org/10.1093/icesjms/fsx057

Stephenson, R. L., S. Paul, M. Wiber, E. Angel, A. J. Benson, A. Charles, O. Chouinard, M. Clemens, D. Edwards, P. Foley, L. Jennings, O. Jones, D. Lane, J. McIsaac, C. Mussells, B. Neis, B. Nordstrom, C. Parlee, E. Pinkerton, M. Saunders, K. Squires, and U. R. Sumaila. 2018. Evaluating and implementing socialecological systems: a comprehensive approach to sustainable fisheries. Fish and Fisheries 19:853-873. https://doi.org/10.1111/ $\underline{\text { faf. } 12296}$

Stephenson, R. L., M. Wiber, S. Paul, E. Angel, A. Benson, A. Charles, O. Chouinard, D. Edwards, P. Foley, D. Lane, J. McIsaac, B. Neis, C. Parlee, E. Pinkerton, M. Saunders, K. Squires, and U. R. Sumaila. 2019. Integrating diverse objectives for sustainable fisheries in Canada. Canadian Journal of Fisheries and Aquatic Sciences 76:480-496. https://doi.org/10.1139/cjfas-2017-0345

Symes, D., and J. Phillipson. 2009. Whatever became of social objectives in fisheries policy? Fisheries Research 95:1-5. https:// doi.org/10.1016/j.fishres.2008.08.001

Thompson, S., R. Stephenson, G. Rose, and S. Paul. 2019. Reshaping fisheries research in Canada: the Canadian Fisheries Research Network. Canadian Journal of Fisheries and Aquatic Sciences 76:671-681. https://doi.org/10.1139/cjfas-2018-0450 
Appendix 1. Southwest New Brunswick Community Values Criteria (MRPD Steering Committee 2009).

\begin{tabular}{|c|c|c|c|c|}
\hline CVC element & Key Question & Example Indicators & Low Score Scenario & High Score Scenario \\
\hline Habitat & $\begin{array}{l}\text { Will policy protect 'Sensitive' } \\
\text { habitat? }\end{array}$ & Location & $\begin{array}{l}\text { Occurs within and/or will } \\
\text { negatively affect a known } \\
\text { area }\end{array}$ & $\begin{array}{l}\text { Does not occur } \\
\text { within/near or have a } \\
\text { negative effect on an } \\
\text { known area }\end{array}$ \\
\hline Species & $\begin{array}{l}\text { Will policy protect non- } \\
\text { target and/or SARs? }\end{array}$ & $\begin{array}{l}\text { Number of bycatch species, } \\
\text { change in conditions that have } \\
\text { impact on species, local presence } \\
\text { and success }\end{array}$ & $\begin{array}{l}\text { Long term measurable } \\
\text { negative impact }\end{array}$ & $\begin{array}{l}\text { No measurable negative } \\
\text { impact }\end{array}$ \\
\hline Chemical \& Biological & $\begin{array}{l}\text { Will policy protect against } \\
\text { hazardous material, invasive } \\
\text { species, eutrophication? }\end{array}$ & $\begin{array}{l}\text { Amount and type of waste } \\
\text { discharged/released in the bay }\end{array}$ & $\begin{array}{l}\text { Chronic use and/or acute } \\
\text { effect of a known pollutant or } \\
\text { contaminant factor }\end{array}$ & $\begin{array}{l}\text { No known pollutant or } \\
\text { contaminant factor }\end{array}$ \\
\hline Physical & $\begin{array}{l}\text { Will policy protect the } \\
\text { natural physical } \\
\text { environment? }\end{array}$ & $\begin{array}{l}\text { Noise generation, light use, } \\
\text { release and/or resuspension of } \\
\text { sediments }\end{array}$ & $\begin{array}{l}\text { Permanent and/or } \\
\text { irreversible negative } \\
\text { measurable impact on the } \\
\text { physical environment }\end{array}$ & $\begin{array}{l}\text { No measurable negative } \\
\text { impact on the physical } \\
\text { environment }\end{array}$ \\
\hline Cumulative Impact & $\begin{array}{l}\text { Will policy consider the } \\
\text { amount of activity, } \\
\text { development in the area? }\end{array}$ & $\begin{array}{l}\text { Number and magnitude of } \\
\text { existing activities/development } \\
\text { in the location }\end{array}$ & $\begin{array}{l}\text { Actively likely to add to } \\
\text { cumulative impacts }\end{array}$ & $\begin{array}{l}\text { Not likely to add to } \\
\text { cumulative impacts }\end{array}$ \\
\hline Heritage Sites & $\begin{array}{l}\text { Will policy protect marine } \\
\text { areas, sites of known } \\
\text { heritage and archeological } \\
\text { interest? }\end{array}$ & Location, type of activity & $\begin{array}{l}\text { Occurs in or on, and will likely } \\
\text { disturb/disrupt/destroy a } \\
\text { known marine } \\
\text { heritage/archeological/ } \\
\text { aboriginal site }\end{array}$ & $\begin{array}{l}\text { Preserves or supports a } \\
\text { known marine } \\
\text { heritage/archeology/ } \\
\text { aboriginal site }\end{array}$ \\
\hline Cultural Heritage & $\begin{array}{l}\text { Will policy be consistent with } \\
\text { local natural and cultural } \\
\text { heritage? }\end{array}$ & $\begin{array}{l}\text { Measureable support of } \\
\text { awareness/educational } \\
\text { opportunities }\end{array}$ & Does not & Does \\
\hline Indigenous Rights & $\begin{array}{l}\text { Will policy protect } \\
\text { indigenous traditions? }\end{array}$ & Access to location/species & Impact use patterns & No impact on use patterns \\
\hline Equal Access & $\begin{array}{l}\text { Will policy protect equal } \\
\text { access to shoreline and } \\
\text { marine space for social } \\
\text { activities? }\end{array}$ & $\begin{array}{l}\text { Number and type of access } \\
\text { points, amount of accessible } \\
\text { marine space }\end{array}$ & $\begin{array}{l}\text { Creates a permanent } \\
\text { displacement/barrier for } \\
\text { shoreline and/or marine } \\
\text { space access }\end{array}$ & $\begin{array}{l}\text { Creates no barriers and/or } \\
\text { enhances shoreline and/or } \\
\text { marine space access }\end{array}$ \\
\hline Community Health & $\begin{array}{l}\text { Will policy contribute to } \\
\text { community health, human } \\
\text { growth? }\end{array}$ & $\begin{array}{l}\text { Number of permanent families, } \\
\text { number of service/education } \\
\text { opportunities }\end{array}$ & $\begin{array}{l}\text { Does not provide for local } \\
\text { "human involvement" or } \\
\text { "community investment" }\end{array}$ & $\begin{array}{l}\text { Provides for local "human } \\
\text { involvement" or } \\
\text { "community investment" }\end{array}$ \\
\hline Public Perception & Public perception & $\begin{array}{l}\text { Number of communications via } \\
\text { gov't/political } \\
\text { officials/media/MRP office }\end{array}$ & High negative & High positive \\
\hline Local Employment & $\begin{array}{l}\text { Will policy support local } \\
\text { employment and local } \\
\text { prosperity? }\end{array}$ & Number of local employment & $\begin{array}{l}\text { No support of local } \\
\text { employment or prosperity }\end{array}$ & $\begin{array}{l}\text { Significant local } \\
\text { employment and } \\
\text { prosperity }\end{array}$ \\
\hline Livelihoods & $\begin{array}{l}\text { Will policy impact on an } \\
\text { existing local economic } \\
\text { livelihood or future } \\
\text { opportunities? }\end{array}$ & Local employment per area & $\begin{array}{l}\text { Negative (Complete } \\
\text { barrier/displacement) }\end{array}$ & Positive (enhancement) \\
\hline Sustainability & $\begin{array}{l}\text { Will policy promote financial } \\
\text { self-sufficiency and } \\
\text { sustainability? }\end{array}$ & $\begin{array}{l}\text { Financial resources (short term } \\
\text { or long term) }\end{array}$ & $\begin{array}{l}\text { Development is dependent } \\
\text { on external financial support }\end{array}$ & $\begin{array}{l}\text { No external startup funds } \\
\text { or ongoing financial } \\
\text { support required }\end{array}$ \\
\hline $\begin{array}{l}\text { Economic } \\
\text { Diversification }\end{array}$ & $\begin{array}{l}\text { Will policy support new local } \\
\text { economic diversification and } \\
\text { ownership? }\end{array}$ & $\begin{array}{l}\text { New industry to the area that } \\
\text { benefits the local economy }\end{array}$ & No & Yes \\
\hline New Investment & $\begin{array}{l}\text { Will policy create new } \\
\text { investment, local economic } \\
\text { spin-offs? }\end{array}$ & $\begin{array}{l}\text { Growth of existing or new } \\
\text { businesses, increases tax base } \\
\text { foreign investment }\end{array}$ & Low & High \\
\hline
\end{tabular}


Appendix 2. Summary of the Canadian Fisheries Research Network framework (Stephenson et al. 2019).

\begin{tabular}{lll}
\hline & \multicolumn{1}{c}{ Objectives } & \multicolumn{1}{c}{ Example Indicators } \\
\hline Ecological & Productivity and Trophic Structure & Recruitment Dynamics \\
& Biodiversity & Species Assemblage Structure \\
& Habitat and Ecosystem Integrity & Pollution \\
Economic & Economic Viability and Prosperity & Human Demographics \\
& Sustainable livelihoods & Livelihood Index \\
& Distribution of Access and Benefits & Equity \\
& Regional Economic Benefits to & Distribution of Catch Income \\
& Community & \\
Social & Health and Well Being & Social Factors \\
& Sustainable Communities & Social Capital \\
& Ethical Fisheries & Rights of Small Scale Fisheries \\
Institutional & Legal Obligations & Legal Obligations to Indigenous \\
& Good Governance Structure & Groups \\
& Effective Decision-making Process & Collaboration \\
& & Accountability \\
\hline
\end{tabular}

